NBER WORKING PAPER SERIES

\title{
WHY SHOULD EMERGING ECONOMIES GIVE UP NATIONAL CURRENCIES: A CASE FOR 'INSTITUTIONS SUBSTITUTION'
}

\author{
Enrique G. Mendoza \\ Working Paper 8950 \\ http://www.nber.org/papers/w8950 \\ NATIONAL BUREAU OF ECONOMIC RESEARCH \\ 1050 Massachusetts Avenue \\ Cambridge, MA 02138
}

May 2002

This paper borrows heavily from joint work with Guillermo Calvo and Katherine Smith. Comments and suggestions from Cristina Arellano and Alejandro Izquierdo are also gratefully acknwoledged. This paper was written while the author was a visiting scholar at the Research Department of the Inter-American Development Bank. The views expressed here are only the author's and do not necessarily reflect those of the Inter-American Development Bank or the members of its staff. The views expressed herein are those of the author and not necessarily those of the National Bureau of Economic Research.

(C) 2002 by Enrique G. Mendoza. All rights reserved. Short sections of text, not to exceed two paragraphs, may be quoted without explicit permission provided that full credit, including (C) notice, is given to the source. 
Why Should Emerging Economies Give up National Currencies:

A Case for 'Institutions Substitution'

Enrique G. Mendoza

NBER Working Paper No. 8950

May 2002

JEL No. F3, F41, E3, E5

\begin{abstract}
Financial contagion and Sudden Stops of capital inflows experienced in emerging-markets crises may originate in an explosive mix of lack of policy credibility and world capital market imperfections that afflict emerging economies with national currencies. Hence, this paper argues that abandoning national currencies to adopt a hard currency can significantly reduce the emerging countries' vulnerability to these crises. The credibility of their financial policies would be greatly enhanced by the implicit subordination to the policy-making institutions of the hard currency issuer. Their access to international capital markets would improve as the same expertise and information that global investors gather already to evaluate the monetary policy of the hard currency issuer would apply to emerging economies. Yet, adopting a hard currency does not eliminate business cycles, rule out all forms of financial crises, or solve severe fiscal problems that plague emerging economies, and it entails giving up seigniorage and potential benefits of conducting independent monetary policy. However, these disadvantages seem dwarfed by the urgent need to enable emerging countries to access global capital markets without exposing them to the risk of recurrent Sudden Stops.
\end{abstract}

\author{
Enrique G. Mendoza \\ University of Maryland \\ Department of Economics \\ College Park, MD 20742 \\ and NBER \\ mendozae@econ.umd.edu
}




\section{Introduction}

Argentina's ongoing economic crisis is the most recent in a long and growing chain of similar debacles that have spread across the so-called emerging economies since the devaluation of the Mexican peso almost seven years ago. The severity and contagion of these crises among this group of economies are unprecedented phenomena that are particular to the era of fastmoving globalized financial markets.

Why have emerging economies, many of which embarked in far-reaching programs of stabilization and market-oriented reform during the 1990s, fared so poorly? A simplistic explanation is "bad government," which results in corrupt, incompetent, or dysfunctional political and legal institutions. Indeed, many emerging economies are plagued by problems such as rampant tax evasion, crony capitalism, non-functioning or non-existent bankruptcy procedures, widespread financial fraud, corrupt judiciary systems, acute political strife, etc. Yet, the findings of the growing body of research on emerging-markets crises show that even "good" governments are likely to be exposed to a high degree of vulnerability to large, sudden reversals of international capital flows, and that faced with those reversals they are likely to proceed as we have observed them to proceed. At the core of this vulnerability lie two fundamental elements: the lack of credibility of domestic policy-making institutions in emerging economies and the imperfections of the globalized capital markets these economies must access to tap the world supply of saving.

The lack of credibility of economic policies in emerging countries can be attributed again to "bad" government, but in these countries even the policies of well-intentioned and benevolent governments would be questioned. The reason is that, for all the emphasis on new features of 
capital markets crises in the era of financial globalization, one key aspect of these crises is old news for citizens of emerging countries: government policy displays a high degree of time inconsistency. The currency pegs and managed exchanged rates announced and implemented in the late 1980s and early 1990s were offered as commitments to stabilization policies that would result in sustainable low inflation. As time passed, however, the policy adjustments needed to stick to this initial commitment became too costly to bear, so adjustments were put off leading to unsustainable levels of exchange rates and financial crises. These crises were then resolved by government policies that engineered large redistributions of wealth within the private sector and from the private sector to the public sector and/or the foreign sector. Governments have done this several times before the crises of emerging markets in the globalization era (witness, for a short list of examples, Chile 1982, Mexico 1976 and 1982, or Argentina, 1990). At the end of each of these debacles, the repenting government promised not to do it again, and to show its commitment it started over with a new set of monetary arrangements it swore to comply with until the next crisis.

The adverse macroeconomic effects caused by lack of policy credibility and imperfect world capital markets are the subject of two well-established but largely separate strands of the international macroeconomics literature. Recently, however, some of the literature on emerging markets crises began to focus on the interaction between these two elements, showing how they combine to create a transmission mechanism that can greatly amplify the effects of adverse exogenous shocks. In an environment in which economic policy is not credible, policy reforms like privatization of public enterprises and financial institutions, or stabilization policies like the widespread use of exchange rate management to reduce inflation, may have fueled the period of 
bonanza that in most cases preceded balance-of-payments crises (see Calvo and Mendoza (1994) and Mendoza and Uribe (2001)). Financial globalization may have created the possibility of large swings in capital flows driven by self-fulfilling expectations, imperfect and/or costly information, and other similar contagion-prone frictions that can cause large international movements of financial capital despite a country's "strong fundamentals" (as in the studies by Cole and Kehoe (1996), Calvo and Mendoza (2000a) and (2000b), Mendoza (2002), and Chang and Velasco (2000)).

The interaction between lack of credibility and capital market imperfections is reflected in the observation that a non-credible government is typically an implicit feature of the mechanisms that drive emerging-markets crises caused by financial frictions. The mechanisms used to date in many theoretical models assume that emerging economies feature short-term, dollar-denominated debt, unhedged currency risks, collateral or liquidity requirements limiting the ability to contract foreign debt, implicit government guarantees offered to domestic banks or borrowers, and macroeconomic policy environments that are highly unstable and costly to evaluate. These are all features that can be attributed at least in part to a government's lack of credibility at home and in world capital markets.

An example of how the interaction between financial frictions and lack of credibility can create a business cycle transmission mechanism capable of reproducing the 'Sudden Stop' phenomenon of emerging markets crises is provided in Mendoza (2002). The paper examines an economy with incomplete insurance markets in which uncertain duration of economic policy has real effects via a mechanism keen to a stochastic tax distortion, and foreign creditors impose liquidity requirements on domestic borrowers. If the economy has a sufficiently large external 
debt, a sudden policy reversal (even if only a low-probability event) triggers a large reversal in capital inflows, a suddenly-binding foreign borrowing constraint, and sharp downward adjustments in economic activity and domestic relative prices. Mendoza (2001) develops a monetary variant of this model and shows that dollarization can yield large welfare gains by eliminating the risk of devaluation of the currency (i.e., the risk of a reversal of exchange rate policy) and by relaxing liquidity requirements on foreign borrowing.

The main point of this article is to argue that abandoning national currencies in emerging economies to adopt a hard currency can be an effective policy to deal simultaneously with the lack of credibility of domestic financial policies and the imperfections of globalized capital markets. This two-prone approach to the problem contrasts with several of the policy recommendations that have been put forward to deal with emerging-markets crises, which typically aim to tackle either the weaknesses of domestic policy-making institutions or the imperfections of world capital markets. Those that view weak domestic institutions as the culprit tend to favor policies that can end pervasive moral hazard problems, including policies favoring floating exchange rate regimes, committing international financial institutions to refrain from providing large bail outs, and allowing for orderly default procedures by sovereign lenders (see Lerrick and Meltzer (2001)). Those that emphasize the imperfections of global capital markets tend to support policies that provide coordinated financial assistance and minimize the risk of financial contagion by aiming to keep countries at their sustainable levels of debt or by supporting emerging-market debt prices at above non-fundamental crash levels (see Calvo (2002) and Calvo, Izquierdo and Talvi (2002)).

This article builds its case for "Euroization" or "Dollarization" by putting together in an 
intuitive manner arguments that have been developed elsewhere in the literature, particularly by Calvo (1998), (2000) and (2002), Calvo and Mendoza (2000a) and (2000b), and Mendoza (2001) and (2002). The article is intentionally short on technical details which are contained in these papers. The central idea is that abandoning national currencies and adopting a hard currency, when seen from the perspective of emerging economies facing non-credible policy-making institutions and imperfect globalized capital markets, can be very beneficial because: (a) it does away with the lack of credibility of monetary and exchange rate policies, and (b) it reduces the informational frictions behind several mechanisms of financial contagion and sudden reversals of capital flows (by rendering unnecessary the costly investment of knowledge and resources that goes into assessing domestic monetary policies).

These arguments on the debate on "Euroization" or "Dollarization" deviate from the more conventional arguments in which the issue is whether it is wise to give up the use of independent monetary policy as a tool for stabilization policy, which itself boils down to the protracted debate on the significance of nominal rigidities and the effectiveness of monetary policy tools. The initial premise here is precisely that independent monetary policy in the class of countries that concern this article is a cause of concern, either because policymaking institutions in these countries are not efficient vehicles for stabilization policy, or because even if they were the global capital market may fail to assess domestic policies with precision and differentiate them from those of other countries in which policies are mismanaged. The aim is thus to think of abandoning national currencies as a vehicle for "institutions substitution," paraphrasing the label of the "imports substitution" approach to economic development that was dominant in developing countries during the 1960s. 
The rest of the paper is organized as follows. Section 2 documents key features of emerging markets crises that point to the central role of non-credible policy and imperfect capital markets in causing the crises. Section 3 reviews some analytical results that suggest that the globalization of (imperfect) financial markets had endogenous mechanisms that increased the vulnerability of emerging economies to suffer Sudden Stops. Section 4 summarizes an analytical framework for studying economic fluctuations in a small open economy that features a transmission mechanism linking imperfections in world capital markets with lack of credibility, or uncertain duration, of domestic economic policy. Section 5 draws policy conclusions.

\section{Sudden Stops and Contagion: Facts and Lessons from Emerging Markets Crises}

Despite heated debate in the aftermath of the 1994 Mexican crash, there is wide agreement now that the emerging markets crises of the 1990s signaled the dawn of a new era in capital markets crises (see Calvo and Mendoza (1996) and (2000a)). This understanding was reached after observing two phenomena common to these crises: the so-called "Sudden Stop" phenomenon and the phenomenon of financial contagion. As Calvo (1998) defined it, a Sudden Stop consists of a sharp and sudden reversal in capital inflows, a corresponding abrupt adjustment in the current account, and sharp declines in production, absorption and the relative prices of goods and financial assets. Sudden Stops occurred in all of the emerging markets crises, perhaps with the exception of the Brazilian crisis of 1999. Financial contagion took place when financial markets seemingly unrelated by any fundamental links to developments in an emerging economy going through a crisis were nevertheless affected and suffered severe effects in terms of price corrections and liquidity. The first example was the "Tequila Effect," by which the Mexican 1994 crises triggered a Sudden Stop in Argentina. The most prominent 
case, however, is associated with the Russian crisis of 1998. Contagion in this case nearly crashed financial markets in industrial countries and triggered a liquidity crisis that forced the Federal Reserve to cut interest rates and coordinate the collapse of hedge fund Long Term Capital Management (LTCM).

Studies like those of Calvo, Izquierdo and Talvi (2002), Calvo and Reinhart (1999), Milesi-Ferretti and Razin (2000) and Mendoza (2002) document in detail the features of the Sudden Stops observed in the emerging countries that suffered financial crises in the 1990s and the last two years. The document by the International Monetary Fund (1999) describes the collapses in equity prices and the increase in their volatility. Mendoza (2002) and Parsley (2001) show evidence of sharp changes in the relative price of nontradable goods for Hong Kong, Korea and Mexico.

Figures 1 to 3 provide a summary view of the stylized facts of Sudden Stops for the cases of Argentina, Korea, Mexico, Russia and Turkey. Figure 1 shows recent time series data for each country's current account as a share of GDP. Sudden Stops are displayed in these plots as sudden, large swings of the current account that in most cases exceeded five percentage points of GDP. Figure 2 shows data on consumption growth as an indicator of real economic activity. These plots show that Sudden Stops are associated with a sharp collapse in the real sector of the economy. Figure 3 provides information on two key financial indicators for each country, the price of domestic equity (valued in U.S. dollars) and the spread of the yield in JP Morgan's Emerging Markets Bond Index Plus (EMBI+) for each country relative to U.S. Treasury bills. Sudden Stops feature large declines in equity prices and sudden, sharp increases in EMBI+ spreads, with equity prices often leading the surge of the spreads at the monthly frequency. 
Empirical studies of contagion disagree on how to define and measure financial contagion, and on whether there is evidence in the data that contagion was common in emerging markets crises (see, for example, Kaminsky and Reinhart (2000) and Rigobon (2002)). Nevertheless, casual observation of Figure 3, keeping in mind the timing of the different crises that took place during the period plotted in the chart, suggests that there was indeed some degree of financial contagion. Moreover, Rigobon's work shows that even when statistically-accurate concepts and measures of contagion are adopted, the data do indicate that there were components of contagion across financial markets during the Mexican and Russian crises.

Underlying economic causes of the Sudden Stop and contagion phenomena cannot be extracted from descriptions of the stylized facts like the one summarized above. In the next two sections, the paper reviews analytical arguments making the case that the uncertain duration of economic policy in emerging economies and the imperfections of globalized capital markets are likely to be the culprits. An important necessary condition for this hypothesis to hold is that global capital inflows into emerging markets show an important component driven by factors external to emerging economies. Calvo, Leiderman and Reinhart (1996) showed earlier on that indeed an important statistical predictor of the surge of capital inflows into emerging markets in the first half of the 1990s was the decline in U.S. interest rates. More recently, one can observe in Figure 4 two important changes in the amount and composition of net private capital inflows into emerging economies (see also Razin, Sadka and Yuen (1998)). First, there was a dramatic and seemingly permanent reduction in total net inflows after the Asian and Russian crises. Total net inflows were 7 times higher at the peak of the capital inflows boom in 1996 than in the year 2000. Second, the composition of net inflows changed dramatically. Bank loans never surged 
and became increasingly negative since 1997, while FDI flows actually increased modestly and remained fairly stable. A deeper analysis would show two additional key facts. First, that an important element of the fall in capital inflows was the protracted retrenchment of the emerging economies bond market induced by the Russian crisis and Ecuador's default on its Brady bonds. Second, that the change in composition of the inflows reflected also changes in the country distribution of inflows, as countries like China or Mexico, recipients of large FDI inflows, fared much better than countries that rely on portfolio or bank loan flows (as Argentina or Ecuador).

The Asian and Russian crises naturally could account for a temporary fall in capital inflows into the countries affected by these crises, but the trends shown in Figure 4 affected all emerging economies and seem to be persistent. From this perspective, the drying up of capital inflows after Russia 1998 would seem to a country like Argentina as exogenous as the boom that Calvo, Leiderman and Reinhart (1996) attributed to the fall in U.S. interest rates in the early 1990s. Thus, emerging countries are clearly vulnerable to large and potentially long-lasting swings in their ability to access global capital markets that are driven to a non-trivial extent by forces beyond their direct control.

\section{Rational Contagion in Globalized Capital Markets}

Making the case that contagion and Sudden Stops are new phenomena in the era of globalized capital markets requires an argument for justifying that financial globalization can indeed trigger large swings in international capital flows that may not be justified by a country's fundamentals. In Calvo and Mendoza (2000a) and (2000b) we presented three economic models that substantiate this argument.

The first model is a model of rational contagion in which global investors are less willing 
to pay for relevant country-specific information as global capital market integration progresses, and hence are more likely to react to "rumors" rather than paying to assess their veracity. In this model, the global capital market consists of a large number of identical "mean-varianceoptimizing" investors that can choose whether or not to pay a fixed cost to eliminate the idiosyncratic uncertainty of the return to an investment in a particular emerging economy. For simplicity, all investment opportunities are ex ante identical and their returns are independently and identically distributed. How does the incentive to pay the fixed information cost (i.e., the gain of paying the cost and designing an optimal portfolio using the updated information relative to investing "blindly" on the basis of the ex ante distribution of returns) vary as the number of emerging economies in the global capital market grows? We showed that as long as the size of short positions that can be taken on specific countries is limited, the incentive to pay the fixed information cost always reaches a point at which it becomes a decreasing function of the number of countries in the market (up to a lower bound at which it becomes independent of market size). The intuition is that the return to "blind" investment is becoming a risk-free return as the number of countries increases while taking advantage of learning a low return for sure on a particular country at a cost requires taking an increasingly large short position on that country.

The second model makes an argument for rational herding among mutual fund managers or investment bankers. Assume that these managers and bankers are again identical, meanvariance optimizers, but now consider that they face an incentive structure that rewards them when they produce "above market" returns and punishes them when the opposite occurs. We showed that if the marginal reward is larger than the marginal punishment, there is a region of multiple optimal portfolios. Within this region, all investors move in a herd to mimic whichever 
portfolio becomes the "day's preferred portfolio." The reason is that holding this portfolio is optimal because investing more (less) would yield a marginal cost higher (lower) than the marginal gain. Moreover, increasing the number of countries in which to invest (in the same fashion as in the first example) widens the multiplicity range up to a point in which this range is maximized and becomes independent of the size of the global capital market.

The third model starts where the fixed-information-cost analysis ended. That is, given that information is costly and the incentives to pay for it for an individual investor fall as the market grows, it makes sense to expect that the market will organize itself into a group of "sophisticated" informed traders and a group of uninformed agents that invest their funds with them. Consider then Calvo's (1999) setup in which the uninformed try to extract information about a country's fundamentals from noisy information they get about the specialists' trades. Informed investors take an action, say buying Argentine bonds, that is observable for uninformed investors but that represents a combination of two variables, one that is an accurate signal of Argentine fundamentals (so that the choice to buy Argentine bonds is increasing on this signal) and another variable that reflects factors that are particular to the informed traders and has a negative effect on the choice to buy Argentine bonds (like margin calls informed traders may get from their own creditors). For simplicity, the observed variable is modeled as the difference of the fundamentals signal minus the investor-specific shock. Uninformed individuals know the unconditional distributions of both (which are standard normal distributions) while specialists know their exact values.

A standard signal extraction problem emerges in this setting: Upon observing the specialists' trade, the uninformed compute the distribution of the fundamentals signal 
conditional on the observed trade, and this conditional distribution has a mean that is decreasing in the "noise-to-signal" ratio (i.e., in the ratio of the variances of the noise variable relative to the fundamentals signal). Hence, if this ratio is low, that is if the variance of fundamentals if high relative to the variance of the noise variable, uninformed investors are more likely to act on the observed trade because their conditional expectation that the trade reflects strong fundamentals is higher. In a limiting case in which the noise-to-signal ratio approaches zero even tough the variance of the noise per se is large, uninformed investors bet that observed trades always signal fundamentals even though they in fact have an important ingredient of noise.

Unfortunately for emerging markets, a low "noise-to-signal" ratio is very likely because of the relatively high cyclical variability of their fundamentals indicators, such as the terms of trade or gross domestic product (see Mendoza (1995)), compared with the rare occurrence of widespread margin calls and liquidity crunches a'la Russian crisis. The contagion of the Russian default that drove investors into liquidating positions across emerging markets worldwide can be interpreted then as the outcome of a low-probability, non-fundamentals shock, e.g., large margin calls, which induced a sizable cut in observed positions of specialized investors in emerging markets that was then largely misinterpreted by uninformed investors as a shock to the fundamentals of emerging economies.

Informational frictions are crucial for the three models reviewed above. For instance, if all investors are equally and perfectly informed, there would always be investors willing to purchase the securities that investors facing margin calls are liquidating at prices that cannot deviate much from the fundamentals prices. Asset prices would then collapse only in the case of a true negative shock to "fundamentals." Short-selling constraints and margin calls (which 
themselves can be interpreted as resulting from informational frictions) are just as crucial. If unlimited short selling were possible, for example, investors would never have reduced incentives to acquire country-specific information at a fixed cost. Moreover, there are reasons to believe that informational frictions are more pervasive in the context of global capital flows to emerging markets than in other asset markets. This is because of the amount and diversity of the information that needs to be gathered on a large set of economic, social and political factors and the expertise required to process it and interpret it. There is also little room for economies of scale in this information-gathering process: collecting information on determinants of asset returns in Korea may be of some help in predicting returns in South East Asia but is of little help in understanding fully returns prospects in Indonesia and is of no use in assessing returns for Latin America.

\section{Non-credible Policy, Financial Frictions and Sudden Stops}

The macroeconomic implications of the temporariness of non-credible government policies is the subject of a large literature in international economics. This literature originated in the seminal papers of Calvo (1986) and Helpman and Razin (1987) (Rebelo and Vegh (1996) and Calvo and Vegh (1999) provide detailed surveys). The starting point of this literature was the observation that in countries in which non-credible stabilization programs were perceived as temporary in the 1970 s and 80 s, consumption boomed in the early stages of the programs and then collapsed at or around the time in which the programs were abandoned. Calvo argued that this could be explained via intertemporal substitution: if the public knows with full certainty that inflation stabilization will be temporary, it is optimal to substitute consumption away from future high-inflation periods into present low-inflation periods. Helpman and Razin approached the 
issue focusing on wealth effects resulting from the fiscal implications of temporary inflation stabilizations, modeling these wealth effects as intergenerational wealth redistributions that break the Ricardian equivalence principle. A temporary currency peg that lowers current inflation redistributes wealth favoring the generations that are alive while the peg is in place and against those that arrive at the time the peg collapses and in the periods that follow.

Mendoza and Uribe (2001) developed a stochastic model in which a non-credible currency peg is the source of uninsurable devaluation risk, which in turn is the driving force of business cycles in a small open economy perfectly integrated to international capital markets. Their analysis incorporates mechanisms similar to Calvo's intertemporal substitution effect and Helpman and Razin's fiscal-induced wealth effect, but in the context of an equilibrium business cycle model in which the private sector formulates optimal plans with regard to consumption of traded and nontraded goods, investment, labor, and money holdings.

The optimal decisions of the private sector are distorted by uninsurable devaluation risk in the following manner. First, uncovered, risk-adjusted nominal interest parity implies that the domestic nominal interest rate features an endogenous time- and state-dependent risk premium relative to the world nominal interest rate that is given by a multiple of the rate at which the public expects the currency to be devalued. The size of this premium depends on the expected decline in wealth caused by the increase in seigniorage associated with the collapse of the currency and the surge in inflation that follows. Second, fluctuations in the nominal interest rate act as a random tax on current labor income, future capital income and the return on saving because money is a risky asset that helps agents economize transactions costs in purchasing consumption and investment goods (a similar outcome obtains in Mendoza (2001) assuming 
instead that money enters directly in the utility function).

In the Mendoza-Uribe setup, a time-varying J-shaped probability of abandonment of a currency peg yields macroeconomic dynamics consistent with several stylized facts of exchangerate-based stabilizations. A J-shaped pattern of devaluation probabilities captures the observation that these stabilization plans start with a very uncertain future (so devaluation probabilities are high when they are introduced), credibility then improves gradually (so devaluation probabilities decline) until a certain point in time in which the survival of the plan is increasingly questioned (so devaluation probabilities begin to rise). Blanco and Garber (1986) and Klein and Marion (1997) provide econometric evidence in favor of this argument.

The currency risk premium implies that a J-shaped pattern of devaluation probabilities yields a similarly-shaped time path of domestic nominal interest rates for the economy attempting to stabilize with imperfect credibility. In turn, the declining interest rate in the early stages of the program favors booms in consumption, investment and employment, a widening current account deficit, a reduction in the expenditure velocity of circulation of money and a real appreciation of the currency (i.e., an increase in the relative price of nontradable goods in terms of tradable goods). These are low-tax periods in terms of the random taxes mentioned above, and they are also periods in which each date that the peg survives the public realizes that actual wealth is higher than expected the date before (since the surge in seigniorage did not materialize). Hence, the model's intertemporal tax distortions and fiscal-induced wealth effect both work to favor the economic boom and real appreciation. As the nominal interest rate touches bottom and starts to increase, the tax-like distortions work in the opposite direction and they can outweigh the fiscal-induced wealth effect (in which case there is a recession that 
predates the collapse of the peg, as observed for example before the devaluations in Mexico in 1994 and in Argentina in 2002).

It is crucial to note that, in contrast with the perfect-foresight studies that dominate the imperfect-credibility or policy-temporariness literature, the devaluation-risk equilibrium business cycle model features the above cyclical dynamics regardless of whether ex-post the currency is devalued or not (earlier models that looked at the effects of uncertain duration of economic policy in partial equilibrium settings include Drazen and Helpman (1988) and Calvo and Drazen (1998)). Thus, the essential element of the analysis is the fact that the stabilization policy anchored on the currency peg is not fully credible, and hence the public expects that a devaluation is possible with some probability in an environment in which currency risk goes unhedged.

The findings of the currency risk model suggest that the analysis of uncertain duration of macroeconomic policies has gone some way in accounting for the stylized facts of temporary or non-credible exchange-rate-based stabilizations. As a framework that can account for Sudden Stops, however, it has an important shortcoming: stabilizing emerging economies are assumed to have access to a perfect, frictionless international capital market in which they can borrow as much as they want as long as they refrain from running Ponzi games. As illustrated below, obtaining in this environment sudden reversals of the current account in response to either a policy reversal or other exogenous shocks of foreign or domestic origin is not possible.

Consider now the possibility that as a result of the informational frictions discussed in Section 2, international capital markets are highly imperfect. The recent literature on the Sudden Stops phenomenon has explored the potential of a large variety of capital-market imperfections 
to act as triggers of Sudden Stops (see the survey by Arellano and Mendoza (2002)). For simplicity, follow Mendoza (2001) and (2002) and Mendoza and Smith (2002) in assuming that these imperfections take the form of foreign borrowing constraints that impose liquidity requirements or collateral constraints on borrowers, and debt contracts that can only be denominated in units of tradable goods for economies with a large nontradable-goods industry (a phenomenon referred to as "liability dollarization," or now also "liability euroization").

A liquidity requirement is used by lenders as an ability-to-pay criterion that helps them manage default risk by requiring borrowers to pay a fraction of their current obligations out of current income, or equivalently by requiring them not to let their total debt to income ratio exceed a certain level. A classic case are the scoring criteria used in mortgage lending by which qualified borrowers are required to satisfy specific ratios of non-mortgage debt payments and total debt payments as a fraction of gross income.

What happens with the predictions of the uncertain-policy-duration framework discussed above when the structure of international capital markets it modified to introduce liquidity requirements? The essential changes are two. First, the liquidity requirement introduces an occasionally-binding constraint on foreign borrowing, by which debt must be less or equal than a certain fraction of the value of domestic income in units of tradable goods. Second, whether this constraint binds or not at a particular date and state of nature is a combined result of the underlying exogenous shocks driving the model and the endogenous dynamics of foreign debt, income generated in the tradables and nontradables sectors of the economy, and the domestic relative price of nontradables in response to those shocks.

In this economy with borrowing constraints, Sudden Stops occur when the country's 
external debt is "sufficiently large" and a "sufficiently adverse" combination of shocks shifts the economy from a situation in which the liquidity requirement was not binding to a situation in which it binds. The "sufficiently adverse" stock of debt and "sufficiently adverse" shocks are those such that the amount by which domestic agents would like to enlarge their foreign debt in the absence of a liquidity constraint by foreign lenders exceeds the level that this constraint allows. The constraint will then be met by a sudden current account reversal and a collapse in private absorption. Moreover, the adjustments in consumption and the current account are magnified if they trigger a collapse in domestic income and/or in the relative price of nontradable goods (i.e., the real exchange rate) because this implies that in addition to the liquidity constraint becoming suddenly binding, the constraint is tightened further by the collapses of income and prices (since debt is denominated in units of tradables but partially leveraged on the sizable income generated by the non-tradables sector).

How strong can the above effects be? To answer this question, consider some of the quantitative simulation results reported in Mendoza (2002). These simulations apply to Mexico as an example of a representative small open, emerging economy. Mexico has large industrial sectors producing and generating income in tradable and nontradable goods, and both goods are also consumed by the domestic private sector. Three exogenous random shocks are introduced to drive Mexico's business cycles: domestic productivity shocks, shocks to the world real interest rate, and shocks that reflect the uncertain duration of economic policy (modeled as regime-switching shocks affecting the rate of depreciation of the currency or a set of direct and indirect tax rates). Mexican national accounts data are used to calibrate the model. The calibration also examines historical data on Mexico's foreign asset position to pin down 
parameter values that allow the model to mimic Mexico's average foreign debt to output ratio and a reasonable value for the liquidity requirement coefficient (i.e., the maximum debt to GDP ratio in units of tradables).

Figure 5 shows the impact effects of a shift from a state with high productivity, low world interest rate, and low policy distortions to a state with the opposite features for different levels of initial net foreign assets, or the negative of foreign debt. The plots show the impact effects for an economy assumed to have access to a perfect credit market and the economy that faces the liquidity requirement.

The results shown in Figure 5 have three key implications. First, if there are no imperfections in international credit markets, there are no Sudden Stops. Even at very high debt levels, the adverse shocks trigger relatively smooth adjustments in the model's endogenous macroeconomic aggregates. Second, for very low or very high debt levels there is also no room for Sudden Stops. With very high debt the borrowing constraint binds regardless of whether the shocks are favorable or unfavorable. With very low debt the constraint never binds and the economy's response to the shocks is nearly identical to that observed in the case in which no credit-market imperfection is present. These are tranquil times in which shifts across good and bad shocks produce relatively smooth business cycles and the economy's access to world capital markets is not compromised. Third, in the range of debt positions just above the level at which the range of debt positions with nonbinding liquidity constraints ends, adverse shocks trigger a suddenly binding borrowing constraint. This is the Sudden Stop range. Here, the equilibrium response of the economy to the same size of adverse shocks to productivity, world interest rate and policy distortions as in the other ranges features a sharp reversal of the current account and a 
major collapse in domestic consumption and production. For part of this range there is a large drop in the relative price of nontradables (the price can also rise because the liquidity constraint induces supply and demand effects in the market of nontradables, and depending on which effect is stronger the price can rise or fall).

The simulations shown in Figure 5 are an imperfect approximation to reality and they follow from a stylized model with many caveats and unrealistic assumptions. Yet, the magnitude of the Sudden Stop adjustments that it produces is striking. Moreover, some of the caveats and unrealistic assumptions of this setting do not apply to other recent quantitative studies that yield the same main prediction: Capital market imperfections are a powerful mechanism for producing Sudden Stops. The literature on quantitative applications of models of emerging markets crises has examined alternatives that consider the role of margin constraints and equity trading costs (Mendoza and Smith (2002) and Cavallo, Kisselev, Perri and Roubini (2002)), costly monitoring of firms by lenders (Cespedes, Chang, and Velasco (2000)), collateral constraints (Paasche (2001) and Christiano, Guts, and Roldos (2002)), working capital (Oviedo (2002) and Neumeyer and Perri (2002)), default risk (Hamann (2002)), debt repayment incentive-compatibility constraints (Arellano (2002)), and current account targets (Valderrama (2002)).

A closer look at the analysis of Mendoza and Smith (2002) can help highlight the interaction between the information costs that distort international capital markets (as argued in Section 2), the determination of emerging markets asset prices, and the business cycle transmission mechanism that drives Sudden Stops. This analysis also brings into play a key feature of credit contracts among players in international capital markets: collateral constraints in 
the form of margin requirements. Factual descriptions of the contagion of the Russian crisis and its connection with the collapse of LTCM describe how widespread margin calls played a central role in precipitating the systemic sale of emerging countries' assets in global capital markets (see the book by Dunbar (2000) and the Wall Street Journal article series published September 22-24, 1998).

Consider a representative foreign securities firm that specializes in trading a small open economy's equity. This firm incurs recurrent transactions costs as well as transactions costs that are a quadratic function of the size of the trades it undertakes. These two transactions costs represent the informational costs alluded two in Section 2. The per-trade costs are important because they imply an elasticity of the foreign traders' demand for emerging markets equity that is inversely related to the per-trade transactions costs. At the limits, if the per-trade cost is zero the trader's demand is infinitely elastic, if the per-trade cost is infinite the demand is perfectly inelastic. The recurrent costs are important because they capture the idea that trading in emerging market assets requires continuos investment in gathering and processing countryspecific information. These costs need to be incurred just to be prepared to trade on a particular emerging country's assets, regardless of whether there is actually any trade, and the costs themselves are unrelated to the size of the trades. For example, understanding Chile's inflation targeting system under its framework of widespread indexation or Mexico's unique setup for conducting monetary policy by adjusting "cortos" (or "shorts") among banking institutions, is a complex, information-intensive task and its cost does not depend on how much a proposed trade in Chilean or Mexican bonds is worth.

In the absence of recurrent trading costs, foreign traders would be willing to hold on to a 
given position on emerging markets assets if and only if the price equals the fundamentals price (defined at the expected present value of dividends discounted at the world real interest rate). They would be willing to buy more if the price is lower than the fundamentals level, and less if the price is above the fundamentals level. In the presence of recurrent costs, however, traders hold on to a given emerging markets asset position only if the price is below fundamentals. Thus, recurrent costs are a necessary condition for the price of emerging markets assets to remain lower than justified by fundamentals even in the long run (when asset positions reach a stationary equilibrium).

The foreign traders trade equity with the corresponding emerging country. Lenders in the global credit market that agents in this country has access to demand to hold as collateral a certain fraction of the market value of the domestic agents' equity holdings. This margin constraint is a collateral constraint that has two unique features: First, custody of the collateral is surrendered to lenders when the debt is contracted, so the typical issues that arise with other collateral constraints related to whether lenders can or want to take over the collateral of a defaulting borrower after it declares default are irrelevant. Second, a fall in asset prices tightens the constraint because it reduces the market value of the assets offered as collateral, thereby allowing the lender to make a margin call on the borrower to make up for the difference. The margin call is automatic and does not require legal proceedings beyond the margin clause already agreed to in the debt contract. Some margin requirements exist as a result of government regulation on the financial industry but they are also widely used as explicit clauses of credit contracts that can take different shapes (value-at-risk collateralization, for example, is a form of margin requirement in which the lender makes margin calls based on its estimate of the potential 
losses that it could face if a worst-case scenario for the particular asset exposure in question materializes).

In this setting, again, a "sufficiently large" initial debt and a mix of "sufficiently adverse" shocks to productivity, world interest rates, and domestic policies shift the economy from a state in which the margin constraint did not bind to one in which it does. But now the process that follows has an extra ingredient that is, to put it simply, a modernized representation of the debtdeflation mechanism pioneered by Irving Fisher (1933). A debt-deflation process starts when the "sufficiently adverse" shocks hit and agents in the emerging economy get an initial margin call. They then rush to "fire-sale" their equity in the global capital market. However, they meet there with foreign traders that have a less-than-infinitely-elastic demand for equity because of the informational costs they incur, and so are only willing to buy the extra equity at a reduced price. If there were no informational costs, the margin call would simply result in an equity reallocation from home agents to foreign traders with no change in emerging markets equity prices. Now the asset price falls and the lenders see that the value of the assets they hold as collateral shrinks. This triggers the margin clauses of debt contracts again and a new round of margin calls. The process is repeated until the equilibrium price settles at a level that satisfies the margin constraint (Mendoza and Smith (2002) ensure that it does by assuming, as was done in Section 2, that agents cannot take unlimited short positions).

A mechanism for financial contagion also emerges from this model. Consider that a Russian-style default triggers a "world liquidity shock" that takes the form of a large increase in the world interest rate. An emerging economy sitting in South America and totally unrelated to Russia may experience a Sudden Stop and a collapse in the prices of its internationally-traded 
assets as a result of the combination of margin constraints and trading costs. An interest-rate shock is a change in fundamentals and as such it should be reflected in what happens to an emerging country's asset prices and economic conditions, but the point is that there can be substantial "overreaction" to this change in fundamentals because of the imperfections of the world's capital market.

\section{Policy Implications: Dollarization, Euroization and What Else?}

It may seem odd that a paper on abandoning national currencies reaches this point without having said much about money and exchange rates (except for the discussion of devaluation risk as a driving force of business cycles). Indeed, the problems that were described with lack credibility of government policy and imperfect international capital markets can exist regardless of the monetary institutions and currency arrangements of a nation. Moreover, it follows from this last observation that giving up the national currency to adopt a hard currency does not rule out financial crises that can look a lot like a Sudden Stop (consider, for example, the Great Depression). When it comes to recent Sudden Stops in emerging economies, however, monetary and exchange rate policies are at the core of the lack of credibility of government policy and the informational frictions behind global capital market imperfections.

An emerging country that gives up completely its national currency for the Dollar or the Euro, and so reduces its central bank to a bank-supervision agency, stands to make several gains: (1) The devaluation risk that has played a central role in the chronic boom-bust cycle associated with the introduction and collapse of managed exchange rates in this class of countries would be greatly reduced. It can never be fully eliminated in as much as a sovereign nation can never credibly commit not to try to reverse course and reintroduce a national currency in the future. 
(2) Foreign investors that have a long history in investing resources and building expertise to track monetary policy in Europe and the United States would no longer need to ponder whether or not to pay for gathering and processing costly information on the monetary policy of each emerging economy they are interested in. This can be interpreted as a sharp decline in information costs, which would translate into better informed investors and reduced vulnerability to herd behavior.

(3) Reduced information costs also increase the demand elasticity for emerging markets equity of foreign traders, which limits the size of asset price declines and Fisherian debt-deflations that could occur on account of frictions like collateral constraints and margin calls.

(4) Financial assets and liabilities would be matched in terms of currency denomination, ending the "liability dollarization" problem that is displaying its crippling macroeconomic effects in the current Argentine crises. Again, a problem with a similar flavor will emerge whenever a sudden, large relative price collapse takes place, but it would be no longer possible for the lack of credibility of domestic monetary or exchange rate policy to generate it.

(5) Considering the contracting environment from which liquidity requirements and collateral constraints emerge, enhanced credibility and reduced informational frictions could result in better access to international capital markets in terms of reduced liquidity coefficients and margin requirements. We know little about how optimal credit contracts would or should react to the adoption of a hard currency in replacement of a national currency, but what was argued here on the basis of findings from the literature is that if liquidity requirements and collateral constraints did fall, vulnerability to Sudden Stops and contagion would be greatly reduced. Regardless of these advantages, emerging countries will not rush to abandon their 
currencies. A national currency is a valued symbol of national identity. It is also a valued and powerful tool for governments to have in difficult times in which it is a lot easier and more discrete to transfer wealth from one set of economic agents to another by simply printing money than by proposing an explicit policy to do it in a democratic environment. There are also the loss of seigniorage and the loss of sovereignty involved in giving up monetary policy-making powers to a foreign nation, and the potential loss of not being able to conduct independent monetary policy to smooth the pains of domestic business cycles. The latter is the less relevant argument, even if perhaps it is the one that often occupies academic and policy debates on exchange rate regimes. The reason is put bluntly in Lucas's (1996) Nobel lecture: “Central bankers and even some monetary economists talk knowledgeably of using interest rates to control inflation but I know of no evidence from even one economy linking these variables in a useful way,..." (p. 666). Even if we had such scientific knowledge, the recent historical record of many emerging economies shows that their policy-making institutions have performed poorly at the task of using independent monetary and exchange-rate policy to preserve price stability and avoid large business cycles. Moreover, even if we had both knowledge and institutions for monetary policy to be useful, the small potential benefit of fine-tuning business cycles would have to be matched up against the five gains of giving up national currencies listed above.

If abandoning national currencies seems a good but unrealistic idea, what else can be done to address the underlying causes of emerging markets crises? Obviously, the alternatives would have to attack the problem indirectly. One set of alternatives considers the possibility of establishing support schemes for the prices of emerging markets assets (see Lerrick and Meltzer (2001) and Calvo (2002)). The premise of these proposals is that either because of moral hazard 
problems (Lerrick and Meltzer) or because of capital market imperfections (Calvo), asset prices of emerging countries can fall sharply below levels warranted by fundamentals and this is a central ingredient of the process driving Sudden Stops. Hence, the international financial organizations could be redesigned to setup facilities that prevent prices from reaching those crash levels. Another alternative is to deepen the internationalization of the financial system, and either secure support for local bank subsidiaries from their foreign owner banks or limit the extent to which those local banks can provide fuel for the liability dollarization process by imposing on them high reserve requirements (i.e., by moving to a framework of narrow banking).

These indirect means to achieve the same goals that Dollarization or Euroization can achieve much more easily seem unduly costly to impose on the citizens of emerging countries, many of which suffer grave economic consequences as a result of recurrent episodes of Sudden Stops and financial contagion. Abandoning national currencies does seem a radical idea, but so did the Euro, the European Union, and the North American Free Trade Agreement not so long ago.

Of course giving up national currencies is not a panacea. It cannot fix many fundamental economic and institutional problems plaguing emerging countries or eliminate forever all forms of financial crises. It is, however, unlike any other currency arrangement in that it ties as tightly as possible the government's hands, so as to prevent it from exercising its confiscatory powers via monetary policy, and in that it simplifies greatly the task of assessing domestic financial policies that is so critical for driving global capital inflows into emerging economies. 


\section{References}

Arellano, Cristina (2002) "Dollarization and Borrowing Limits," mimeo, Department of Economics, Duke University.

, and Enrique G. Mendoza (2002), "Business Cycles in Small Open Economies with Credit Frictions: An Equilibrium Approach to Emerging Markets Crises," NBER Working Paper No.8880, National Bureau of Economic Research, http://papers.nber.org/papers/W8880

Blanco, Herminio, and Peter M. Garber (1986), "Recurrent Devaluation and Speculative Attacks on the Mexican Peso," Journal of Political Economy, v. 94, p. 148-166.

Calvo, Guillermo A. (2002), "Globalization Hazard and Delayed Reform in Emerging Markets," mimeo, Center for International Economics, Department of Economics, University of Maryland.

, Alejandro Izquierdo and Ernesto Talvi (2002), "Sudden Stops, the Real Exchange Rate and Fiscal Sustainability: Argentina's Lessons," mimeo, Research Department, Inter-American Development Bank.

(2001), "Capital Markets and the Exchange Rate with Special Reference to the Dollarization Debate in Latin America," Journal of Money, Credit and Banking, 33(2), 312-334

(2000), "Balance of Payments Crises in Emerging Markets: Large Capital Inflows and Sovereign Governments." In Currency Crises, Paul Krugman ed. Chicago: University of Chicago Press.

(1999), "Contagion in Emerging Market: When Wall Street is the Carrier," manuscript, www.bsos.umd.edu/econ/ciecalvo.htm.

(1986), “Temporary Stabilization: Predetermined Exchange Rates,” Journal of Political Economy 94, 1319-29.

(1998), "Capital Flows and Capital-Market Crises: The Simple Economics of Sudden Stops," Journal of Applied Economics, v.1, pp 35-54.

and Carlos A. Vegh (1999), "Inflation Stabilization and BOP Crises in Developing Countries" in Handbook of Macroeconomics, Vol 1C (North-Holland, 1999), edited by J. Taylor and M. Woodford.

, Leonardo Leiderman, and Carmen M. Reinhart (1996), "Inflows of Capital to Developing Countries in the 1990s," Journal of Economic Perspectives, Spring, 123-140. and Allan Drazen (1998), "Uncertain Duration of Reform: Dynamic Implications," Macroeconomic Dynamics. 
and Carmen M. Reinhart (1999), "When Capital Inflows come to a Sudden Stop:

Consequences and Policy Options," mimeo, Center for International Economics, Department of Economics, University of Maryland.

and Enrique G. Mendoza (2000a), "Capital-Market Crises and Economics Collapse in

Emerging Markets: An Informational-Frictions Approach,” American Economic Review: Papers and Proceedings, May.

and Enrique G. Mendoza (2000b), "Rational Contagion and the Globalization of

Securities Markets," Journal of International Economics, v.51.

, and Enrique G. Mendoza (1996), “Mexico’s Balance of Payments Crises: A Chronicle of

a Death Foretold," Journal of International Economics, v. 41, pp. 235-264.

, and Enrique G. Mendoza (1994), "Trade Reforms of Uncertain Duration and Real

Uncertainty: A First Approximation," IMF Staff Papers, December.

Cavallo, Michelle, Kate Kisselev, Fabrizio Perri and Nouriel Roubini, (2002), "Exchange Rate Overshooting and the Cost of Floating," mimeo, Stern School of Business, New York University.

Cespedes, Luis, Roberto Chang and Andres Velasco (2000), "Balance Sheets and Exchange Rate Policy," mimeo, Department of Economics, New York University.

Chang, Roberto and Andres Velasco (2000), "Banks, Debt Maturity and Crises," Journal of International Economics, Vol. 51, No. 1, pp. 169-194.

Christiano, Lawrence J., Christopher Gust and Jorge Roldos (2000), "Monetary Policy in an International Financial Crisis," mimeo, Research Department, International Monetary Fund, Washington DC.

Cole, Harold L. and Timothy J. Kehoe, (1996), “A Self-Fulfilling Model of Mexico’s 1994-95

Debt Crisis,” Journal of International Economics, v. 41.

Drazen, A. and Elhanan Helpman(1988), "Stabilization with Exchange Rate Management Under Uncertainty," in Economic Effects of the Government Budget, ed. by E. Helpman, A. Razin and E. Sadka, MIT Press, Cambridge:MA

Dunbar, Nicholas, (2000), Inventing Money: The Story of Long Term Capital Management and the Legends Behind It, John Wiley \& Sons, New York: NY.

Frankel, Jeffrey and Sebastian Edwards (2002), Preventing Currency Crises in Emerging Markets. A National Bureau of Economic Research Conference Report. Chicago: University of Chicago Press, forthcoming. 
Fisher, Irving (1933), “The Debt-Deflation Theory of Great Depressions," Econometrica 1, 33757.

Hamann, Franz (2002), "Sovereign Risk and Macroeconomic Volatility," mimeo, Department of Economics, North Carolina State University.

Helpman, Elhanan and Assaf Razin (1987), "Exchange Rate Management: Intertemporal Tradeoffs," American Economic Review, vol. 77, pp.107-123.

International Monetary Fund (1999), International Capital Markets, September, International Monetary Fund, Washington:DC.

Kaminsky, Graciela L. and Carmen M. Reinhart (2000), "On Crises, Contagion, and Confusion,” Journal of International Economics, v. 51, pp.145-168.

Klein, Michael W. and Nancy P. Marion, (1997) "Explaining the Duration of Exchange-Rate Pegs," Journal of Development Economics.

Lerrick, Adam, and Allan H. Meltzer (2001), "Blueprint for and International Lender of Last Resort," mimeo, Carnegie Mellon University.

Lucas Jr., Robert E. (1996), “Nobel Lecture: Monetary Neutrality,” Journal of Political Economy, v. 104, 661-682.

Mendoza, Enrique G. (2002), "Credit, Prices, and Crashes: Business Cycles with a Sudden Stop." In Preventing Currency Crises in Emerging Markets, Frankel, Jeffrey and Sebastian Edwards eds. Chicago: University of Chicago Press, forthcoming.

(2001), "The Benefits of Dollarization when Stabilization Policy Lacks Credibility and Financial Markets are Imperfect," Journal of Money, Credit and Banking, 33(2),

(1995), "The Terms of Trade, The Real Exchange Rate and Economic Fluctuations," International Economic Review, v. 36, 101-137, February.

(1991a), "Real Business Cycles in a Small Open Economy," American Economic Review, v. 81, 797-818, September.

(1991b), "Capital Controls and the Gains from Trade in a Business Cycle Model of a Small Open Economy,” IMF Staff Papers, September, v. 38, 480-505.

, and Katherine A. Smith (2002), "Margin Calls, Trading Costs and Asset Prices in Emerging Markets: the Financial Mechanics of the 'Sudden Stops' Phenomenon," mimeo, Department of Economics, Duke University. 
and Martin Uribe (2001), "Devaluation Risk and the Business Cycle Implications of Exchange Rate Management," Carnegie-Rochester Conference Series on Public Policy, 53.

Milesi-Ferreti, Gian Maria, and Assaf Razin (2000), "Current Account Reversals and Currency Crises:Empirical Regularities." In Currency Crises, Paul Krugram ed. Chicago: University of Chicago Press.

Neumeyer, Pablo and Fabrizio Perri (2001), "Business Cycles in Emerging Economies: The Role of Interest Rates," mimeo, Department of Economics, New York University.

Oviedo, Pedro (2002), "Business Cycles in Small Economies with a Banking Sector," mimeo, North Carolina State University.

Paasche, Bernhard (2001), "Credit Constraints and International Financial Crises," Journal of Monetary Economics, v.28, 623-650.

Parsley, David (2001), “Accounting for Real Exchange Rate Changes in East Asia,” Hong Kong Institute of Monetary Research working Paper No. 6/2001, July.

Razin, Assaf, Efraim Sadka, and Chi-Wa Yuen, (1998), “A Pecking Order Theory of Capital Flows and International Tax Principles," Journal of International Economics, 1998

Rebelo, Sergio and Carlos A. Végh, (1996), "Real Effects of Exchange-Rate-Based Stabilization," NBER Macro Annual, National Bureau of Economic Research, Cambridge: MA.

Rigobon, Roberto, (2002), "Contagion: How to Measure It?", in Preventing Currency Crises in Emerging Markets, Frankel, Jeffrey and Sebastian Edwards eds. Chicago: University of Chicago Press, forthcoming.

Valderrama, Diego (2002), "The Impact of Financial Frictions on a Small Open Economy: When Current Account Borrowing Hits a Limit," Ph.D. dissertation, Department of Economics, Duke University. 
Figure 1. Current Account Balances in Percent of Gross Domestic Product
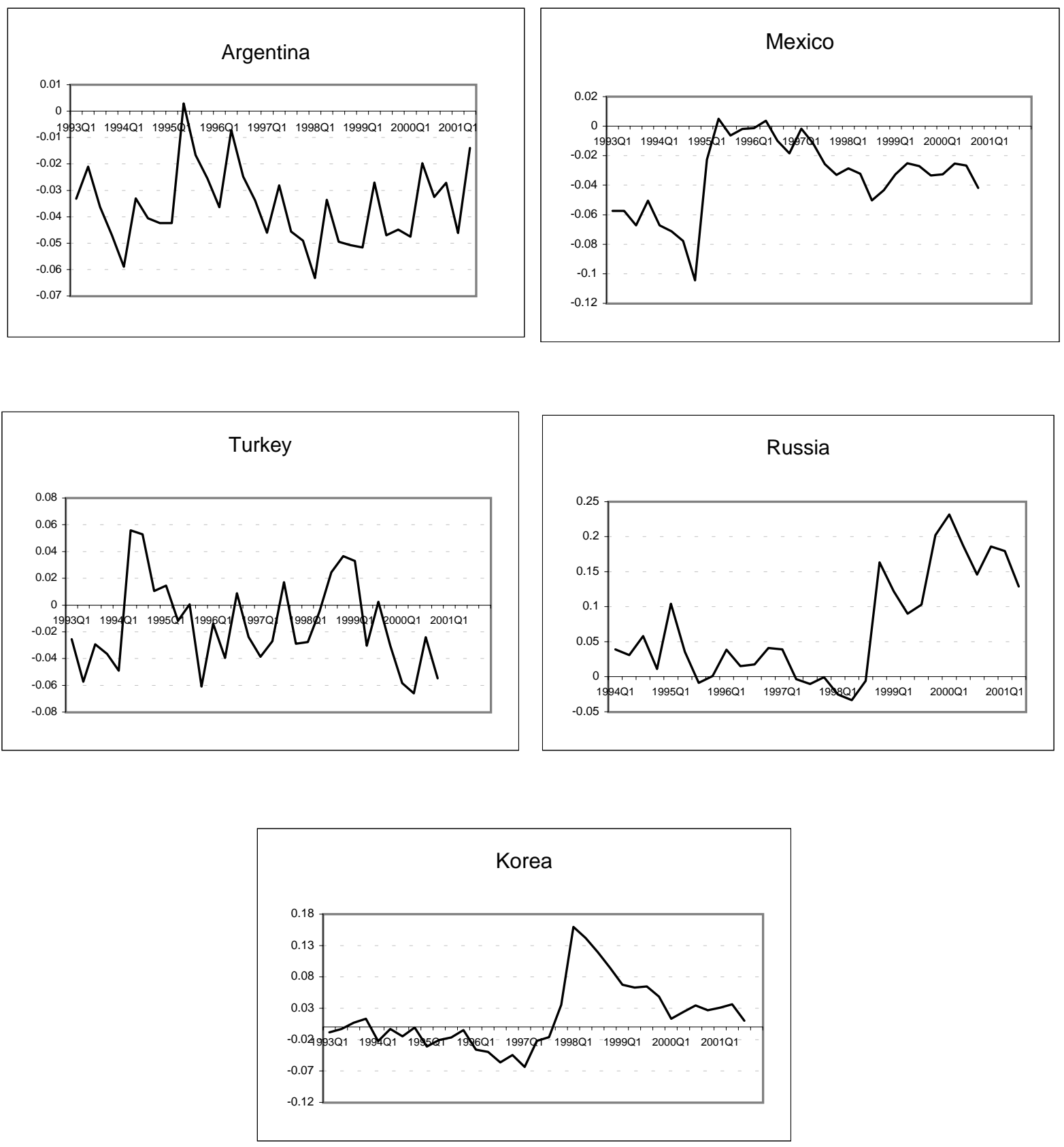

Source: International Financial Statistics, IMF 
Figure 2. Annual Growth Rates in Real Private Consumption Expenditures
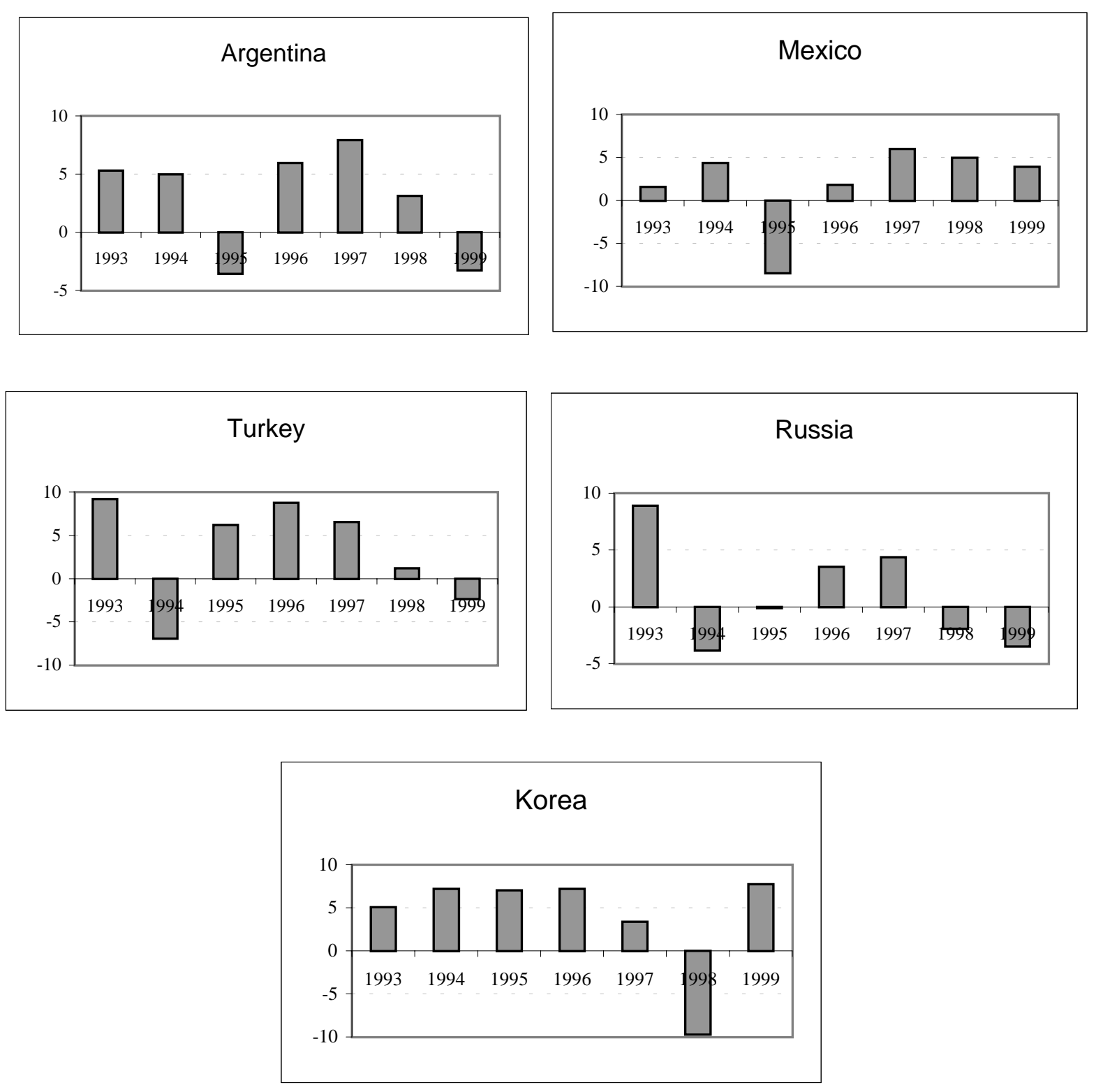

Source: World Development Indicators, World Bank 
Figure 3. Equity Prices and Country Risk
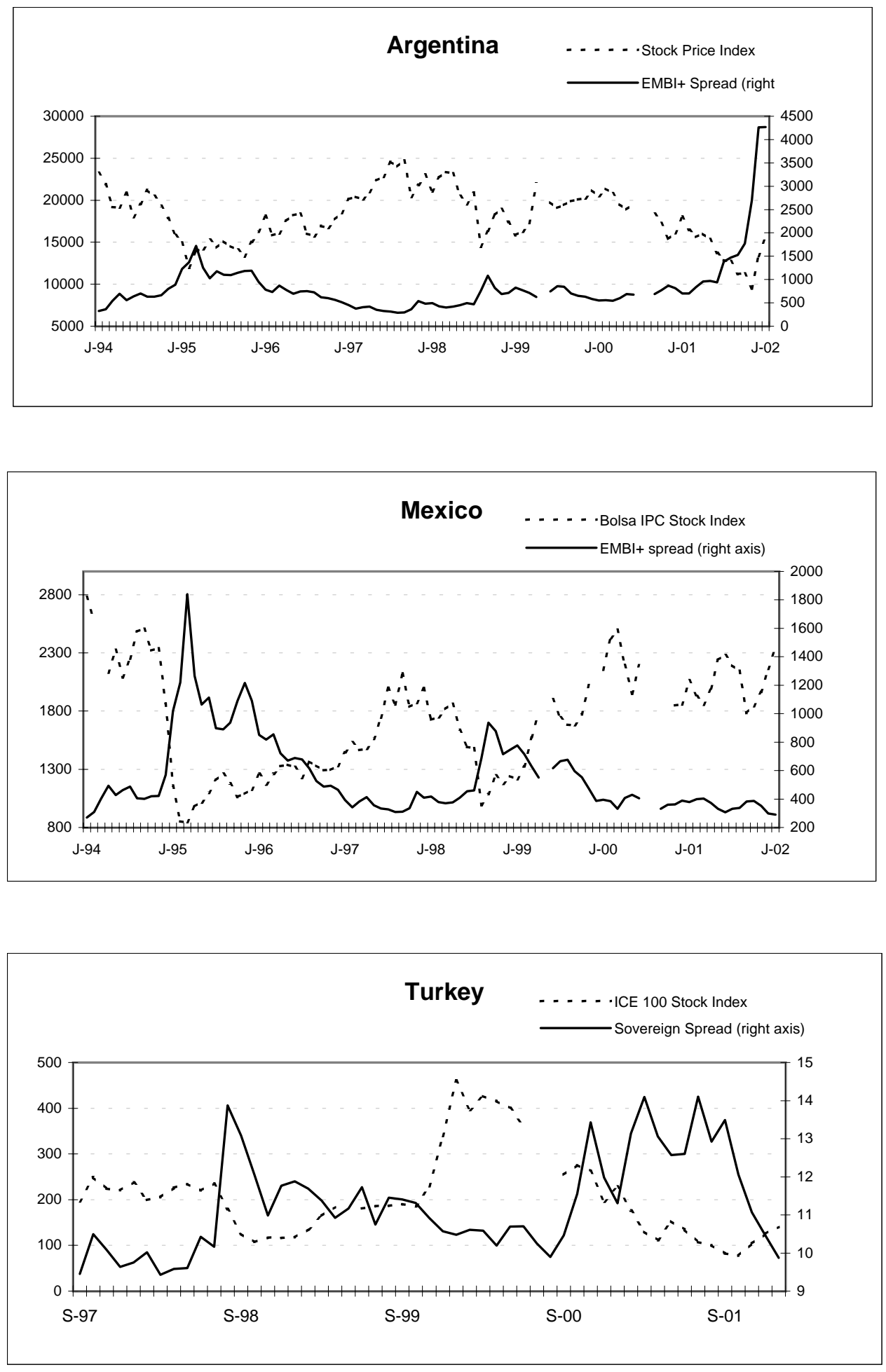
Figure 3. Equity Prices and Country Risk (continued)
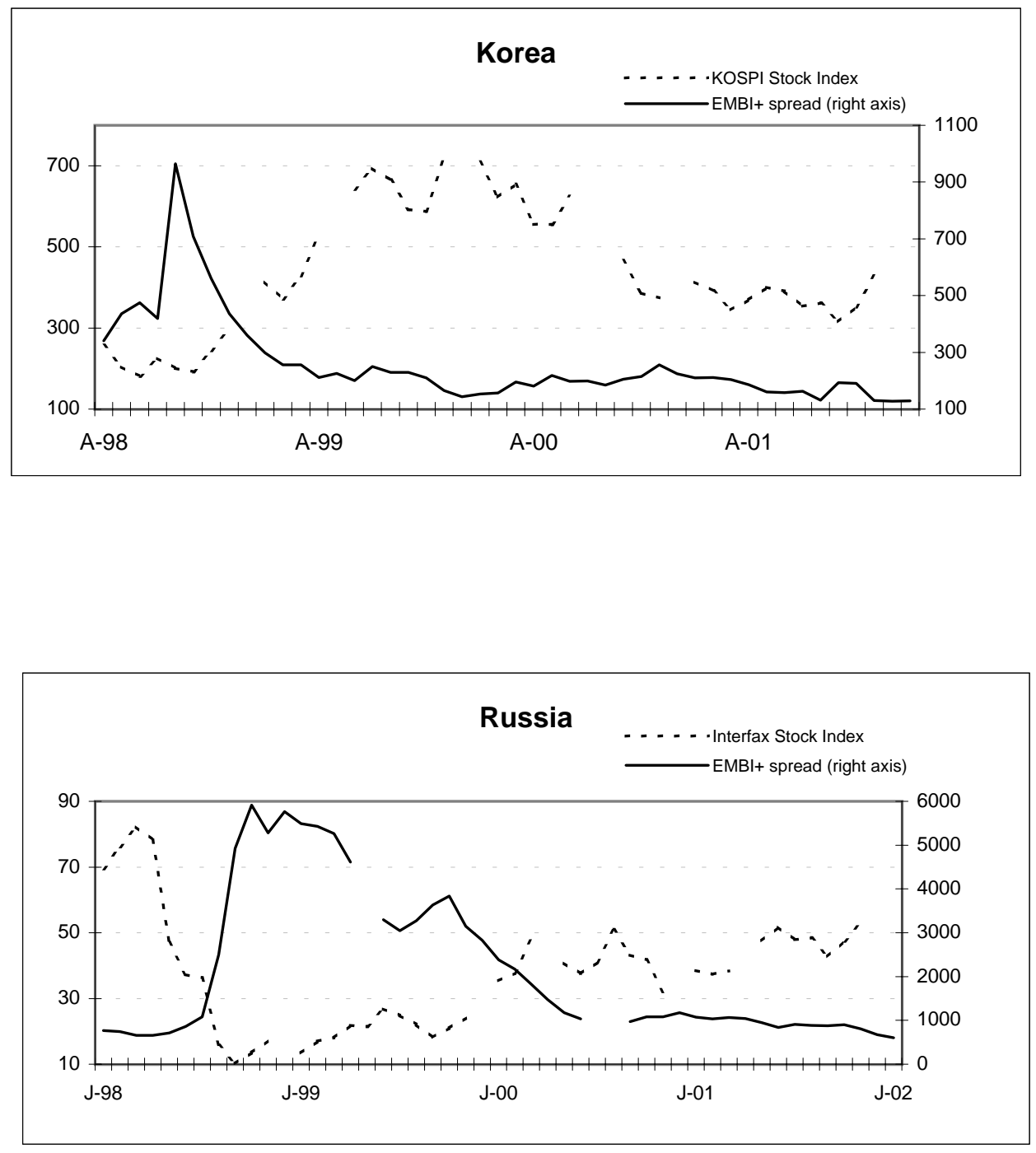

Source: JPMorgan 
Figure 4. Net Private Capital Flows to Emerging Markets

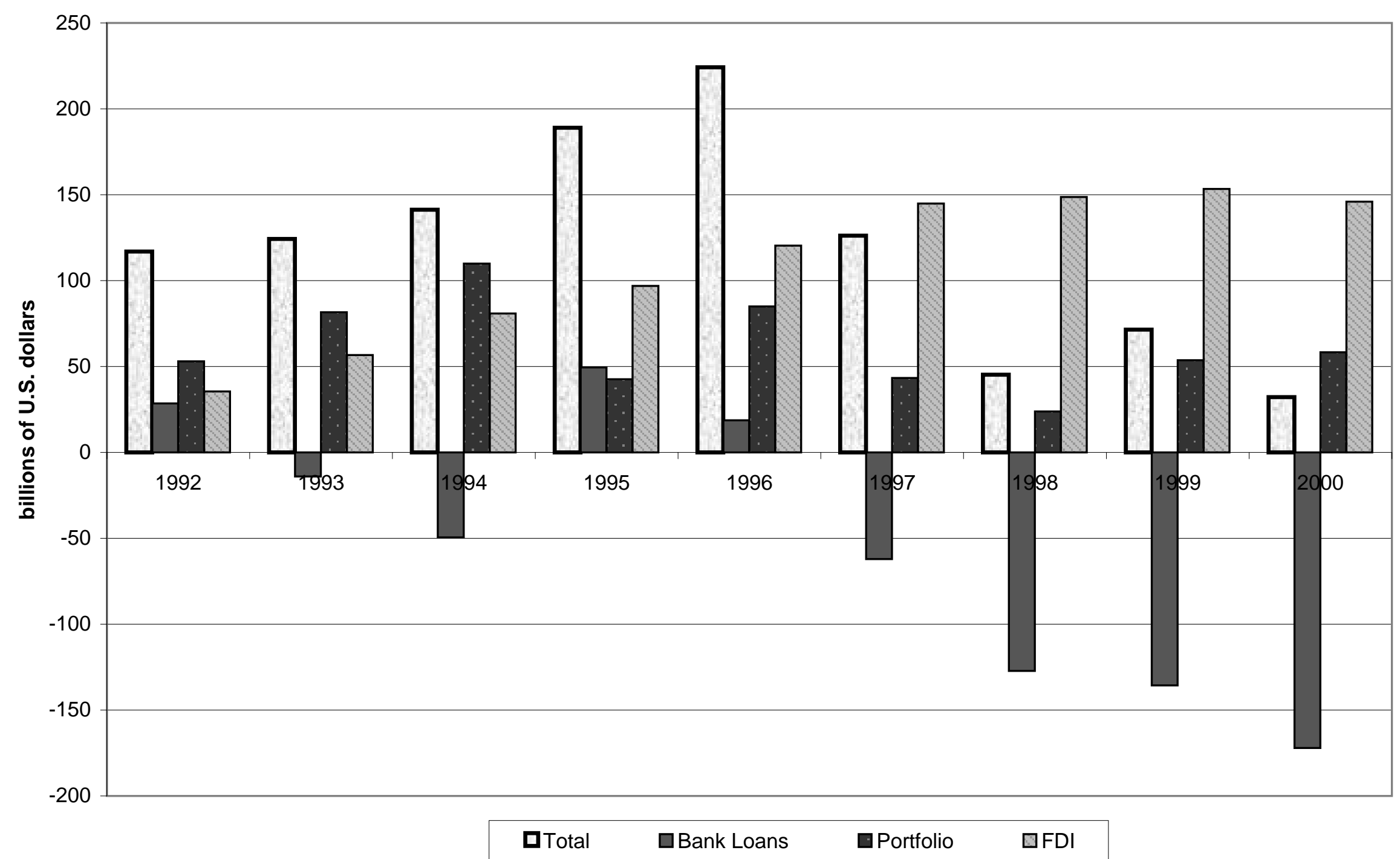


Figure 5. Impact Effects of a Shift from "Best" to "'Worst" State

(as a function of the foreign asset grid)
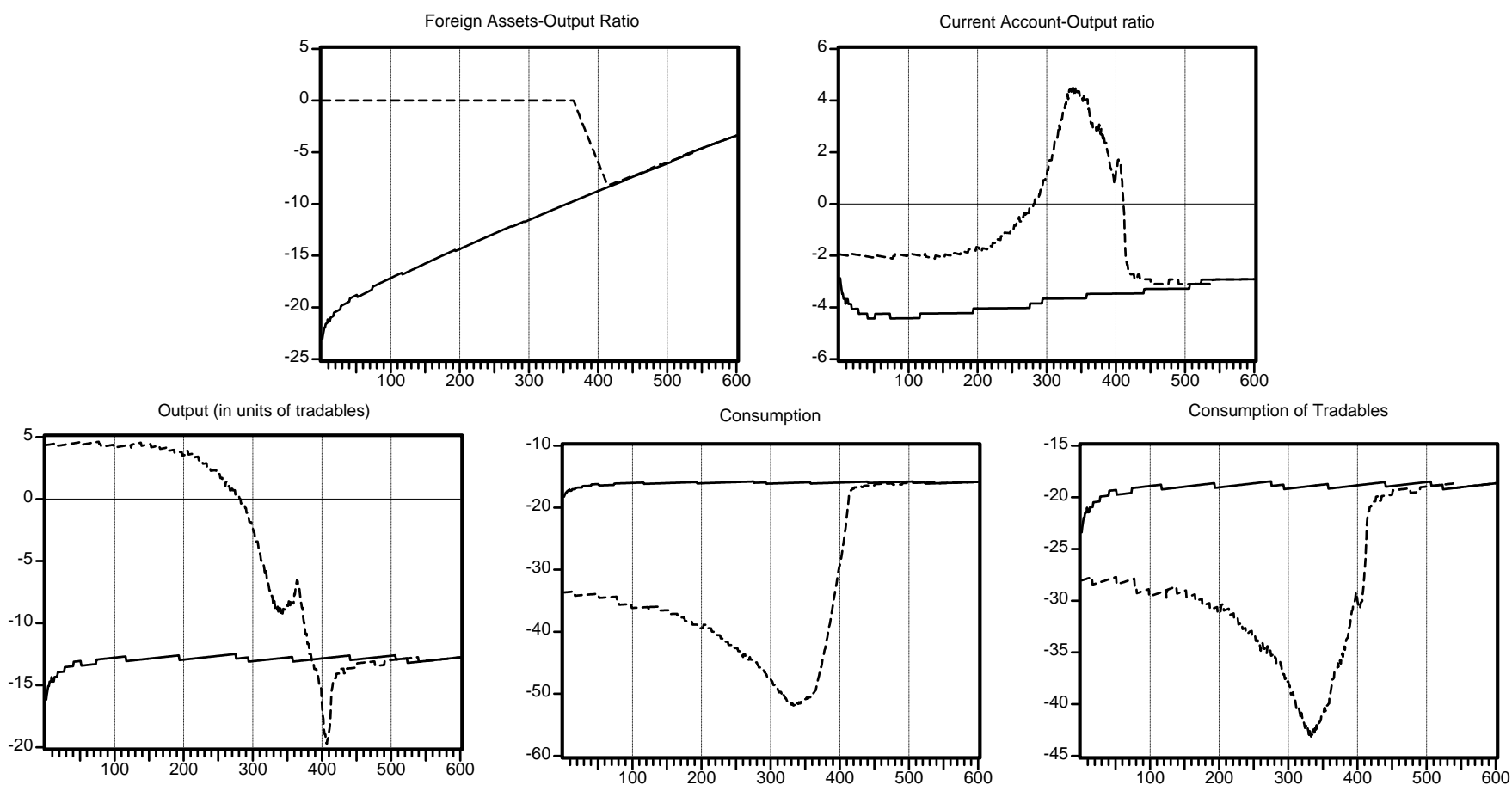

Labor
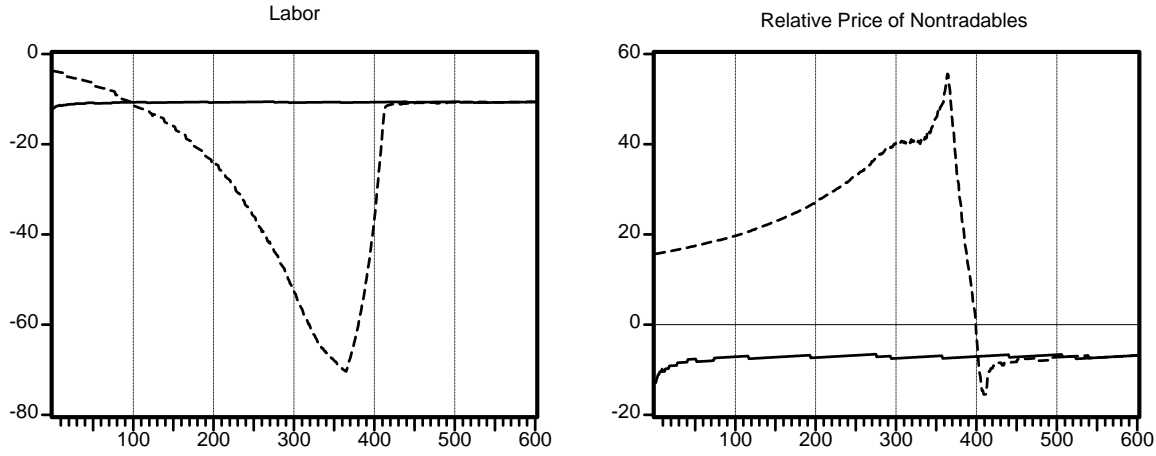

Output of Nontradables

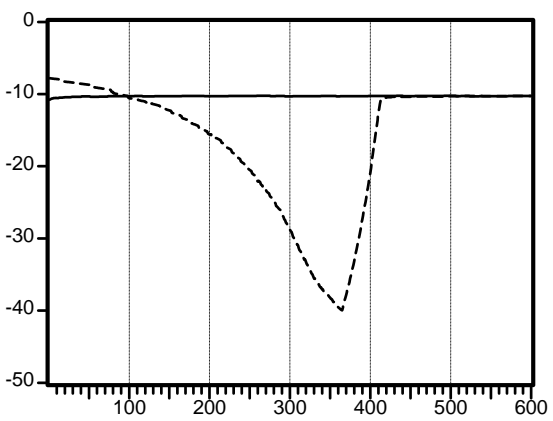

- economy w. perfect credit market --- liquidity constrained economy 